\title{
CONNECTIONS USING SOCIAL NETWORKS AND SOCIAL INTELLIGENCE OF STUDENTS
}

\section{Belma Duvnjak ${ }^{1}$ \\ Jasna Bajraktarević}

\author{
Teaching Faculty in Mostar
}

Received: 14.04 .2013

Accepted: 20.04.2013
Original scientific paper

UDC:159.95:004.738.5

\begin{abstract}
Social intelligence is the ability and skills to cope with everyday life situations and how to cope with interpersonalrelationships.

Today's generation of relationships based, carried and nurtured through various social networks. The aim of the presented research is to identify the impact of social networks on the development of social intelligence. The study was done on a sample, which makes the 208 students from the Faculty of Education at the University "Džemal Bijedić" in Mostar. The results show that the impact of social networks on the development of positive social intelligence. Greater achievement on tests of social intelligence (SI) were significantly correlated with the amount of time spent as korisknik different social networks.
\end{abstract}

Key words: social intelligence, social networks, the Internet.

\section{INTRODUCTION}

Social Intelligence (SI) is a relatively new field in psychology and a new subject of psychological research. Edward Thornidike, a psychologist at Columbia University, first proposed the concept of "social intelligence" in an article published in Happer Monty's Magazine, 1920. He stressed the importance of interpersonal effectiveness to success in many areas of life (Goleman, 2008). According to generally accepted definitions, social intelligence is the ability to successfully insights relationships and develop interpersonal skills to solve problems and to respond appropriately in interpersonal relationships (Dunđerović, 2005). For everyday interpersonal relationships social interactive intelligence has the greatest significance.
"Interpersonal intelligence is the ability to self-consciousness, morality, responsibility, and even spirituality." (Diamnod \& Hopson, 2002, p.197). Degree of interpersonal intelligence conditioned our direction and attitude in interacting with other people.

Ekstravetnost and introvetnost are the personality dimensions that describe the way we function in social contacts, orientation to himself or to his surroundings. Ekstravetna person likes dynamic environment, energy collected through social contacts, is communicative, take the initiative, in the center of attention. Introvert is more focused on himself, finds pleasure in the activities of the self, is not interested in a large number of contacts (Caprara \& Cevrone, 2003).

\footnotetext{
${ }^{1}$ Correspodence to:

Belma Duvnjak, Teaching Faculty, University of "Džemal Bijedić" Mostar

Address: Mile Budaka 117, Mostar, B\&H

Phone.: +387 061/815-039

E-mail: belma.duvnjak@unmo.ba
} 
Today, at a time when communication skills are a must extroverts benefits. On the other hand, the degree of social intelligence also affects our interpersonal orientation. People with high social intelligence are often a source of positive behavior, and make other people feel about them are treasured, loved, respected, and these people are very attractive to others, and are often described as a "magnet"(downloaded 11.08.2012. from the Website: http://www.aboutintelligence.co.uk/social-intelligence.html).People with lower degree Social intelligence are often described as "poison" because people provoke feelings of anger, depression, frustration, guilt. They are often alienated / lonely people. In the past few decades, we have witnessed a significant increase in the use of information and communication technologies. New information technologies have created an entirely new social groups, and thus new ways of communicating. "The word in its broadest sense, and it is spoken and unspoken one, located at the beginning of human existence and accompanies him during his entire life. She creates and it develops interpersonal, face-toface, direct communication, or talking, is a hallmark of human beings. "(Brajša, 2000, p. 8). The development of modern technology has enabled the Internet user enters a virtual world where he himself lives and works. Creating a social network can be a real, real world (on the street, at school, etc) or within social networks that are not a new concept, but in different forms have always existed. New social groups - social networks by nature are neutral, however, the manner and the context of their use determines their impact. The nature of man as a social being is to be located in constant looking to communicate with other people. Fast life, work, family, 'Life on Wheels' has led to the fact that our social life is very cramped. This is one of the reasons that people become members and users of social networks. In this way, people create a community that allows us to socialize 'anytime, anywhere'. This fact significantly affects the lives of individuals, families and society as a whole. Create an online social network is enabled through social software and websites, and among the most famous and the most popular are Facebook, MySpace, Twitter, You Tube... Facebook as the most popular social network has become a new way of communicating, and therefore a new form of society, which imposes new forms behavior (Kušić, 2010).

\section{RESEARCH METHODOLOGY}

Transvezalnu research presents a study aimed to ascertain the views of students on social networks, and to show the connection between social networks and social intelligence in students. The study was conducted in the period from November 2011th by May 2012.

The study used the method of theoretical analysis, survery methods, descriptive methods, statistical methods.

\section{Problem research}

The problem of this study relates to the importance of social intelligence and its upgrades through life under the influence of the social context in which the individual develops.

In 21th Ages themselves are aware of the fact that social networks are playing an increasingly important role socialization process and the general development of the individual. Therefore this study points to the inevitable impact, and good and bad sides, the modern social context. Also, that blindness to this issue opens the door for even more - up social autism.

\section{The sample of respondents}

The study was done on a sample, which makes the 208 students from the Faculty of Education at the University "Džemal Bijedić" in Mostar, Departments of Psychology, Sociology and Classroom teaching. The age of participants ranges from 18 to 40 years. The studies vary in the number of students from 12 to 48 . Of the total 208 respondents and second years of the 67 patients, III is 70 years old and IV, and V = 71 years.

\section{Measuring instruments}

The instrument used in the survey was translated and modified (Bajraktarevic, Duvnjak, 2012). For this study. Module consists of two parts. The first part consists of questions of socio-demographic type (gender, age, department, years of study, student status, employment status, use of social networks-membership and quantity). The second part consists of a scale I and II. No. I do scales: 
Scale Social Intelligence - NE (Petrson \& Seligmans, 2004). To test the level of social intelligence respondents have been divided scale social intelligence. The scale consists of 10 statements that differ in the direction of action. A set of seven statements $(1,2,3,4,5,7,10)$ refers to the social intelligence (claim 7 , alpha $=0.76)$. The task was for each claim of assessing whether and how much relates to him / her on a scale of 1 to 5 where 1 is marked as "completely disagree" and 5 as "strongly agree."

Interpersonal orientation scale - IO (Bezonović, 2002) with the intention of measuring attitudes towards generalized others. Subscale needs of people of eight claims 1, 3, 4, 6, 8, 9, 10, 13 claims as 'For me it is important to always be with other people'. The task was for each claim of assessing whether and how much relates to him / her on a scale of 1 to 5 where 1 is marked as' generally disagree "and 5 as" strongly agree. "
While the scale of Test II consists of Internet addiction - IAT (Kimberly Young)- test consists of 20 questions that measures mild, moderate and severe levels of dependence on the internet.

\section{Methods of data processing}

Statistical analysis of data was performed by SPSS 14.0 for Windows. The data were used in statistical procedures Pearson's r, Chi-square test and ANOVA.

\section{RESULTS AND DISCUSSION}

The first problem of this study was to investigate the relationships between social intelligence and social networks. We conducted a correlation $r$ to make sure you are a social network (IAT and the amount of time spent on the Internet) associated with social intelligence.

Table 1. The corellation between variables social intelligence and social networks

\begin{tabular}{llll}
\hline & Social & How many hours a \\
$\mathbf{N = 2 0 8}$ & intelligence & $\begin{array}{l}\text { Internet } \\
\text { addiction }\end{array}$ & $\begin{array}{l}\text { week they spend } \\
\text { Online }\end{array}$ \\
\hline $\begin{array}{l}\text { Social } \\
\text { intelligence }\end{array}$ & 1 &, 056 & $\mathbf{- , 1 7 0}(*)$ \\
& &, 420 &, 014 \\
Internet addiction & 208 & 208 & 208 \\
&, 056 & 1 &,$- 386(* *)$ \\
How many hours a week they &, 420 & 208 &, 000 \\
spend Online & 208 &,$- 386(* *)$ & 1 \\
&,$- 170(*)$ & 208 & 208 \\
\hline
\end{tabular}

$\mathrm{p}<0.05 ; \mathrm{p}<0.01$

The obtained correlation coefficients showed that social intelligence spent hours online and statistically significantly correlated $(r=-0.17, p<0.05)$ at a significance level with the risk of 5\%. Negative sign tells us that the greater social intelligence (the higher the score on the scale) is associated with a greater number of hours on the Internet.
Surprisingly, however, this is probably a mild correlation indicates that the more hours on the Internet spend some social people achieve more contacts and so on. This essentially reject the hypothesis of the negative impact of social networks and hours spent on the internet, because we get more hours on the Internet, the higher SI. Shown in Table 1. 
In Table 1. the results of that talk about the connection between the SI and the IAT's. Internet addiction as measured by the IAT was not significantly associated with social intelligence. Here you can see an expected finding, which says that the IAT and the hours spent on the Internet related -, 386 $(* * 2)$ is also negative, which means that more hours means more to online internet addiction.

To check whether the students are given the social intelligence and the use of social networks, we divided the subjects into two groups with respect to social intelligence. One group consists of respondents 7-23 degrees - a group with a low SI, and the second group consists of those respondents 28-35 - the group with high SI. We did that through the transformation.

In order to determine whether the two groups with regard to the hours spent on the Internet and IAT-in we used analysis of variance. One-way analysis of variance is a statistical method that considers the group together and draws conclusions based on the entire variability.

Table 2. Differences between subjects with regard to the degree of social intelligence

\begin{tabular}{lcc}
\hline & F & Sig. \\
Internet addiction &, 167 &, 684 \\
\hline $\begin{array}{l}\text { How many hours a week they } \\
\text { spend Online }\end{array}$ & $\mathbf{8 , 2 1 0}$ &, 005 \\
\hline
\end{tabular}

The results follow the direction of relationship we have received and indicate that the number of hours spent in the social network affects the social intelligence $(\mathrm{F}=8.210)$, and so that those who have higher levels of social intelligence spend more hours on the Internet $(\mathrm{M}=1.56 ; \mathrm{SD}=, 939)$. Those who have lower SI spend less time on the internet $(\mathrm{M}=2.12 ; \mathrm{SD}=1,159)$. Exploration conditionally confirmed the positive impact of the Inter- net on the social development of man.

In order to determine the differences in relation to the academic year, the number of friends (online and in real life) was conducted chi-square test. The resulting chi-square $\left(\chi^{2}=9.312, \mathrm{p}>0.05\right)$ was not significant at the $5 \%$ level, and it can be concluded that students of different years of college do not differ with respect to the number of friends online or in everyday life.

Table 3. The study of the relationship and the amount of online friends in real life

\begin{tabular}{|c|c|c|c|c|c|c|c|}
\hline & \multirow{2}{*}{\multicolumn{5}{|c|}{ Years of Study }} & \multirow[b]{3}{*}{ Total } \\
\hline & & & & & & & \\
\hline & & first & second & third & quarter & fifth & \\
\hline \multirow[t]{3}{*}{ More frineds.thi. } & 1,00 & 5 & 8 & 6 & 13 & 0 & 32 \\
\hline & 2,00 & 22 & 25 & 55 & 38 & 13 & 153 \\
\hline & 3,00 & 4 & 3 & 8 & 5 & 2 & 22 \\
\hline Total & & 31 & 36 & 69 & 56 & 15 & 207 \\
\hline
\end{tabular}

More frineds.thi.* yeras of study

${ }^{2}(*$ lower value because the scale is reversed in this variable - from daily to several times a week) 


\section{CONCLUSION}

Social intelligence is reflected in our every move. Social world and relationships that take place within it are guiding towards human development. Communication before the Internet era, and later, one of the factors that affect the social development of man. Social networks as a leading online media communication, so. "Miles 21st century", is an essential factor in the development of social intelligence. The results of our study is conditionally confirmed the impact of social networks on the development of social intelligence, as saying the results obtained.

Research demonstrates the positive impact of using the Internet, because of the existing social networks and spending time hanging out with other people, communication, creation of an new acquaintances leading to satisfying the need for companionship with sociable people. Hypothetically speaking, a possible explanation of the obtained results are a starting point for further and deeper research, is to actually socially intelligent people use the Internet in more constructive purposes (socializing, establishing contacts, meeting new people ...) compared to the others that are on the scale of social intelligence were ranked lower.

\section{REFERENCES}

Brajša, P. (2000). Umijeće razgovora. Pula: C.A.S.H. Caprara, G.V. i Cevrone, D. (2003). Ličnost : determinante, dinamika i potencijal. Beograd: Dereta.

Diamnod, M. i Hopson, J. (2002). Čarobno drveče uma: kako razvijati inteligenciju, kreativnost $i$ zdrave emocije vašeg djeteta od rođenja do adolescencije. Lekenik: Ostvarenje.

Dunđerović, R. (2005). Osnovi psihologije menadžmenta. Novi Sad: Fakultet za menadžment.

Goleman, D. (2008). Socijalna inteligencija. Zagreb.: Mozaik knjiga.

Internet:

Dayu Internet Overuse Solution, the solution for internet overuse and online addiction. Online: http://www.internetoveruse. $\mathrm{com} / \mathrm{p}=171$. Downloaded 15.3.2012. from the website:http:// www.globaladdiction.org/dldocs/GLOBALADDICTIONScales-InternetAddictionTest.pdf

Kušić, S. (2010). Online društvene mreže $i$ društveno umrežavanje kod učenika osnovne škole: navike facebook generacije. Izvorni znanstveni članak. Zivot i škola: časopis za teoriju i praksu odgoja i obrazovanja, (24), str. 103-125. Downloaded 10.2.2012. from the website: http://hrcak.srce.hr/63281 Socijalne/Lične/Emocionalne Inteligencije je skala Petrson\&Seligmans (2004) downloaded 12.3.2012.from the website: http://ipip.ori.org/newVIAKey.htm).

The Theory od Multiple Intelligences, downloaded 11.08.2012. from the website: http://www.aboutintelligence.co.uk/socialintelligence.html 